ZOOLOGIA 32 (6): 485-491, December 2015

http://dx.doi.org/10.1590/S1984-46702015000600008

\title{
Biotic potential and reproductive parameters of Spodoptera dolichos (Lepidoptera: Noctuidae) in the laboratory
}

\author{
Débora G. Montezano, 1,2, Daniel R. Sosa-Gómez ${ }^{3}$, Silvana V. Paula-Moraes ${ }^{4}$, \\ Vânia F. Roque-Specht' ${ }^{5}$, Edegar Fronza², Neiva M. Barros² \& Alexandre Specht ${ }^{4, *}$
}

\author{
${ }^{1}$ Department of Entomology, University of Nebraska. Lincoln, NE 68583, USA. \\ 2 Programa de Pós-graduação em Biotecnologia, Universidade de Caxias do Sul. Caixa Postal 1352, $95070-560$ Caxias \\ do Sul, RS, Brazil. \\ ${ }^{3}$ Laboratório de Entomologia, Embrapa Soja. Caixa Postal 231, 86001-970 Londrina, PR, Brazil. \\ ${ }^{4}$ Laboratório de Entomologia, Embrapa Cerrados. Rodovia BR-020, km 18, Caixa Postal 08223, 73310-970 Planaltina, \\ DF, Brazil. \\ ${ }^{5}$ Faculdade UnB Planaltina, Universidade de Brasília. Área Universitária 1, Vila Nossa Senhora de Fátima, \\ 73345-010 Planaltina, DF, Brazil. \\ *Corresponding author. E-mail: alexandre.specht@embrapa.br
}

\begin{abstract}
The biotic potential and reproductive parameters of Spodoptera dolichos (Fabricius, 1794) were evaluated under controlled conditions $\left(25 \pm 1{ }^{\circ} \mathrm{C}, 70 \pm 10 \% \mathrm{RH}\right.$ and 14 hour photophase). The longevity, pre-, post- and oviposition periods, fecundity, and fertility of 25 couples were evaluated. The longevity of females (12.9 days) was not significantly different than that of males (12.4 days). The mean durations of the pre-, post- and oviposition periods were 3.0, 0.4 and 10.4 days, respectively. The mean fecundity was 4,086.0 eggs per female and mean fertility was 3,557.8 larvae per female. On average, a female copulated 1.4 times. The biotic potential of $S$. dolichos was estimated at $7.138 \times 10^{18}$ individuals/ female/year. The net reproductive rate (Ro) was 1,711.98 times per generation and the mean generation time (T) was 56.19 days. The intrinsic rate of increase $(\mathrm{rm})$ was 0.133 , with a finite rate of increase $(\lambda)$ of 1.142 per day. These results are compared with other species from Spodoptera and their relevance for management strategies of $S$. dolichos.
\end{abstract}

KEY WORDS. Armyworm; development; fecundity; reproduction; spermatophore.

Spodoptera dolichos (Fabricius, 1794) has been reported in most countries of the American Continents (e.g., SiLva et al. 1968, Fergusson et al. 1991, Pogue 2002, Pastrana 2004). Larvae have the potential to consume 94 different plants belonging to 33 botanical families (MontezANo et al. 2015), including crops, weeds, ornamental plants and seedlings in nurseries in different countries (e.g., Silva et al. 1968, Pogue 2002, Pastrana 2004).

The present study complements a previous one on immature $S$. dolichos (MonTEZANo et al. 2015), by evaluating and describing the developmental biological parameters of $S$. dolichos. Special emphasis is placed on the biotic potential and life and fertility tables of the species, obtained under controlled conditions. Since there is no published information on to the biology of $S$. dolichos to compare our results with, we compared them with data on Spodoptera albula (Walker, 1857) and Spodoptera eridania (Stoll, 1782), specimens reared under the same conditions (MonteZANo et al. 2013b, 2014a).

\section{MATERIAL AND METHODS}

The insects and laboratory conditions were the same utilized for immature stages (MontezAno et al. 2015). Only first generation specimens were used in the experiments.

To rule out possible copulation incompatibilities, which have been reported between biotypes from host plants from different locations, (Murúa \& Virla 2004, Murúa et al. 2008, Sadek $\&$ ANDERSON 2007) the insects used in our experiment were from the first generation obtained from a cohort of four females and five males collected in the field (see Montezano et al. 2015).

To avoid the effect of pupal weight on reproductive characteristics (TISDALE \& SAPPINGTON 2001), pupae were weighed on the second day after metamorphosis, and only adult females from pupae weighing between 0.69 to $0.78 \mathrm{~g}$ and adult males from pupae weighing between 0.68 to $0.74 \mathrm{~g}$ were used in the experiment. In addition, to avoid the effects of age on copula-

2015 | Sociedade Brasileira de Zoologia | www.sbzoologia.org.br | www.scielo.br/zool All content of the journal, except where identified, is licensed under a Creative Commons attribution-type BY. 
tion (Kehat \& Gordon 1975, Ellis \& Steele 1982, Rogers \& Marti JR 1994), couples were formed with adults that emerged on the same date.

Adults were kept in pairs $(n=25)$ within cylindrical plastic containers (10 cm in diameter and $15 \mathrm{~cm}$ high) to which 20 filter paper strips ( $12 \mathrm{~cm}$ long and $1 \mathrm{~cm}$ wide) were attached at the upper edges of the container, to stimulate oviposition. The containers were closed at the top with plastic film and at the bottom with Petri dishes $(10.5 \mathrm{~cm}$ diameter) lined with filter paper. The diet of adults was composed of honey (10g), sorbic acid (1g), methylparaben (1 g), sucrose (60 g), and distilled water $(1000 \mathrm{ml})$ (HofFMANN-CAMPO et al. 1985). All components were dissolved in distilled water and the resulting solution was kept under refrigeration $\left(7^{\circ} \mathrm{C}\right)$ until it was used. Pilsen beer was added to the solution daily at a proportion of $1: 4$, beer/ diet, and made available to the insects in a $5 \mathrm{~cm}$ Petri dish lined with cotton wool. Additionally, autoclaved water was provided in another $5 \mathrm{~cm}$ cotton-lined Petri dish. Containers were examined daily to record adult survival, and to remove and count the number of eggs. Dead females were dissected to determine the number of spermatophores they had received from males during copulation.

The fecundity (number of eggs per female), fertility (number of hatched larvae per female), longevity and duration of the pre-oviposition, post-oviposition and oviposition periods were determined. To estimate fertility, we determined the viability of 53 egg masses ( $N=6,485$ eggs) taken from four mated couples. Each egg cluster was placed in a Petri dish, which was lined with filter paper moistened with distilled water until larval eclosion. All evaluated egg masses were from females that had at least one spermatophore in the bursa copulatrix. The presence of spermatophores was determined after death to check if females had been fertilized during the experiment.

All the biological parameters were analyzed using descriptive statistics. The fecundity and longevity of both sexes and the duration of pre- and post- oviposition periods were correlated (Pearson Product Moment Correlation) with the number of mattings of each couple. Owing to the high correlation of the parameters with respect to the number of matings, only the overall average longevity values were compared using the t-test assuming unequal variances, at a significance level of $5 \%$. Between-couple comparisons of the pre-oviposition, oviposition, longevity and fecundity were performed using ANOVA, with the number of spermatophores as factors, and the means were separated by Tukey's test at 5\% probability.

After gathering the biological parameters, the Biotic Potential (BP) was calculated considering the resistance of the environment as being null, using the equation described in Silveira Neto et al. (1976), BP $=(s r \text { * d })^{\mathrm{n}}$ - er, where: $(\mathrm{sr})$ sex ratio is number of females divided by number of females plus number of males; (d) viable individuals per female consisting of the number of eggs per female (or fecundity) multiplied by total survival; (n) number of generations per year or 365 days divided by the total lifespan; and (er) environmental resistance, in this case considered as null.

The biotic potential and fertility life tables were developed using data from the immature stages of $S$. dolichos reared in accordance with the methodology of MonTEZANo et al. (2015). The data is graphically presented by plotting the probability of survival values at the midpoint of each time interval, (survival rate - lx), and the total number of eggs per female per week which became females (specific fertility $-\mathrm{mx}$ ).

Using the life table, the values of the different reproductive parameters of $S$. dolichos were calculated. The net reproductive rate (Ro), given by the ratio between the number of females in two successive generations, the mean generation time $(\mathrm{T})$, which is composed of the mean number of days from the birth of the parents to the birth of the offspring; the daily intrinsic rate of increase $(\mathrm{rm})$ and the daily finite rate of increase $(\lambda)$, followed the formulas given by Silveira Neto et al. (1976).

\section{RESULTS}

Table 1 presents the longevity of $25 \mathrm{~S}$. dolichos couples, females and males, the mean length of their post-, pre- and oviposition, and their mean fecundity. Using the data on egg viability (97.5\%) of 4,086.0 eggs, the mean fertility was 3,557.8 larvae per female.

Table 1. Means, standard deviation (SD) and range of longevity, pre-, post- and oviposition periods and fecundity of 25 couples of Spodoptera dolichos, under controlled conditions $\left(25 \pm 1^{\circ} \mathrm{C}, 70 \pm\right.$ $10 \% \mathrm{RH}$ and 14 hour photophase).

\begin{tabular}{clrrc}
\hline Sex & Biological parameter & \multicolumn{1}{c}{ Mean } & \multicolumn{1}{c}{ SD } & Range \\
\hline Both & Longevity (days) & 12.94 & 2.92 & $7-24$ \\
Female & Longevity (days) & 13.52 & 3.39 & $9-24$ \\
& Pre-oviposition (days) & 3.04 & 1.54 & $2-7$ \\
& Post-oviposition (days) & 0.44 & 0.51 & $0-1$ \\
& Oviposition (days) & 10.40 & 2.52 & $6-17$ \\
& Fecundity (eggs) & $4,085.96$ & $1,589.35$ & $1,029-6,306$ \\
Male & Longevity (days) & 12.36 & 2.27 & $7-17$ \\
\hline
\end{tabular}

Comparisons of male and female mean longevity using a Student t-test, considering different variances, at $5 \%$ level of significance ( $n s-p=0.163$ ).

The average number of copulations per female was 1.40 times. While four $(16.0 \%)$ females did not copulate, ten copulated only once $(40.0 \%)$, eight copulated twice $(32.0 \%)$ and three copulated three times (12.0\%). A strong positive correlation was observed between the number of copulations and fecundity ( $\mathrm{r}=0.939, \mathrm{p}<0.001)$, along with a negative correlation between the number of copulations and duration of the preoviposition period $(\mathrm{r}=-0.664, \mathrm{p}=0.001)$, oviposition period $(-0.490, \mathrm{p}=0.013)$ and longevity $(\mathrm{r}=-0.554, \mathrm{p}=0.004)$. 
The mean daily number of eggs from unfertilized females was smaller than from females that were fertilized once or more often, along with an increase in the length of the pre-oviposition period (Fig. 1). The pre- and oviposition periods of females not fertilized were significantly longer (Figs. 2-3). Such differences were responsible for the increased longevity of the unfertilized females with respect to females that were fertilized. Similarly, a reduction in the longevity of males responsible for fertilizing females was observed (Fig. 4). The fecundity of females was positively affected by the number of matings: females that were not fertilized oviposited less than one third the number of eggs than those that were fertilized, with significant differences between unfertilized females and females that were fertilized once and twice (Fig. 5).

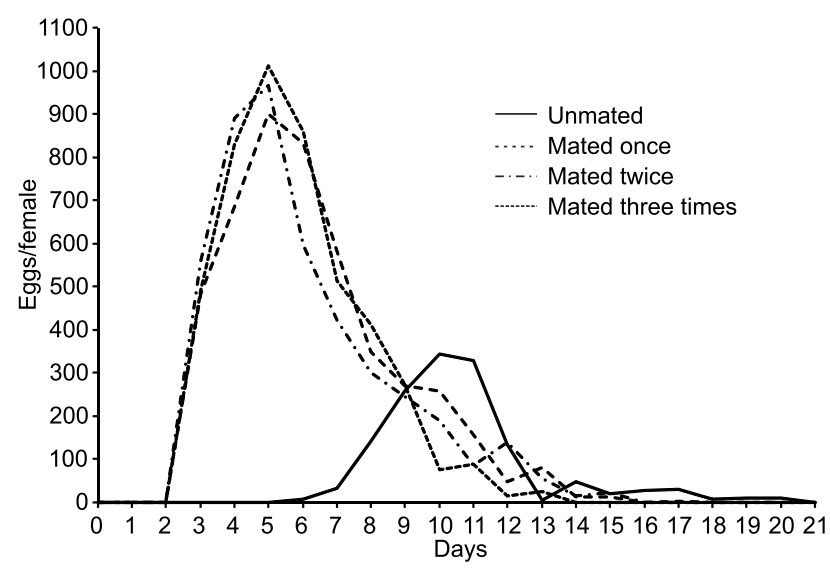

Figure 1. Daily mean number of eggs of Spodoptera dolichos that unmated $(n=4)$, mated once $(n=10)$, twice $(n=8)$ or three times $(n=3)$. One couple per cage at $25 \pm 1{ }^{\circ} \mathrm{C}, 70 \pm 10 \% \mathrm{RH}$ and a 14 hour photophase.

The biotic potential was calculated from the equation BP $=\left(\mathrm{sr}^{*} \mathrm{~d}\right)^{\mathrm{n}}-\mathrm{er} \mathrm{BP}=(0.51 \times 3,557.8)^{5.78-0}$ and determined $7.1 \mathrm{x}$ $10^{18}$ individuals per female per year. Calculation considered that 137 female and 131 male immatures reached the pupal stage, at a ratio of 0.51 . On average, each female oviposited 4,086.0 eggs and the overall survival was $87.1 \%$, resulting in $3,557.8$ viable individuals per female period. The average duration of the life cycle (63.1 days) corresponds to 5.78 generations per year (n), considering the environmental resistance as null.

The maximum rate of population growth occurred between days 54 and 56, during the 7/8th week of life, represented by the intersection of the specific survival and fecundity lines (Fig. 6). This rate is shifted towards the beginning of the adult phase, especially driven by the higher fertility and low mortality of immature individuals, soon after emergence.

The net reproductive rate (Ro) was 1,711.98 females per generation, the mean generation time (T) was 56.19 days, the
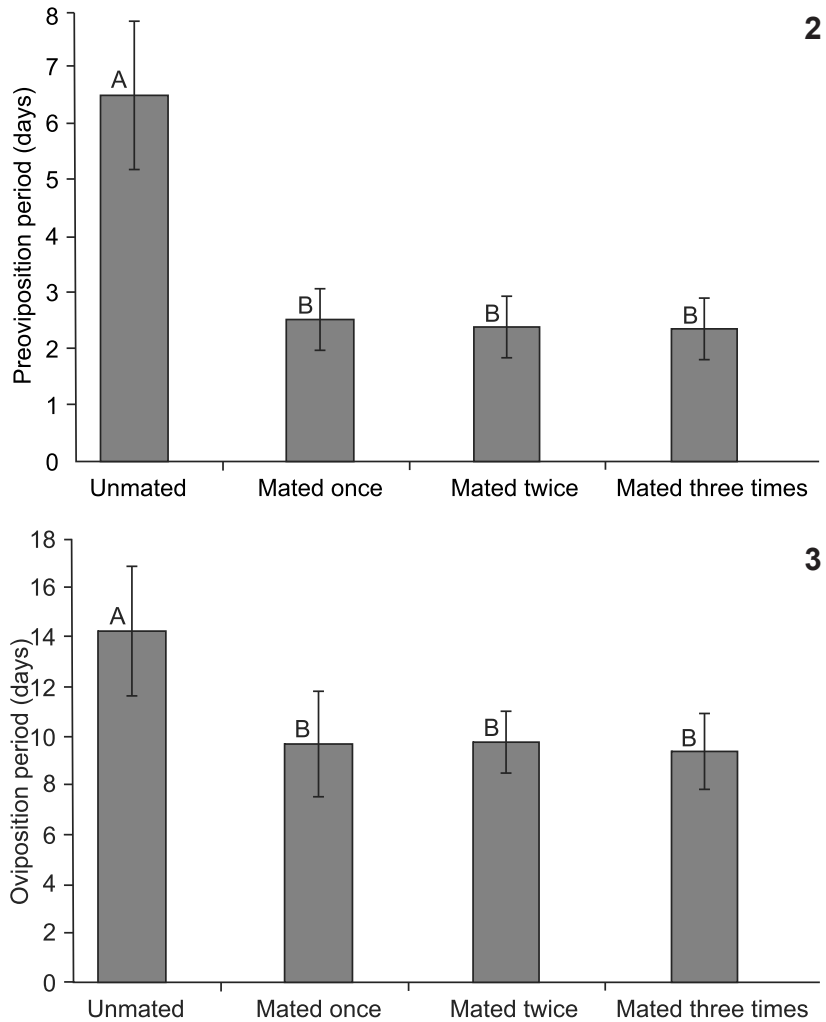

Figures 2-3. Pre-oviposition (2) and oviposition (3) periods of Spodoptera dolichos that unmated $(n=4)$, mated once $(n=10)$, twice $(n=8)$ or three times $(n=3)$. One couple per cage at $25 \pm$ $1{ }^{\circ} \mathrm{C}, 70 \pm 10 \% \mathrm{RH}$ and a 14 hour photophase. Means followed by the same letter are not statistically different from each other by Tukey test, at $5 \%$ probability.

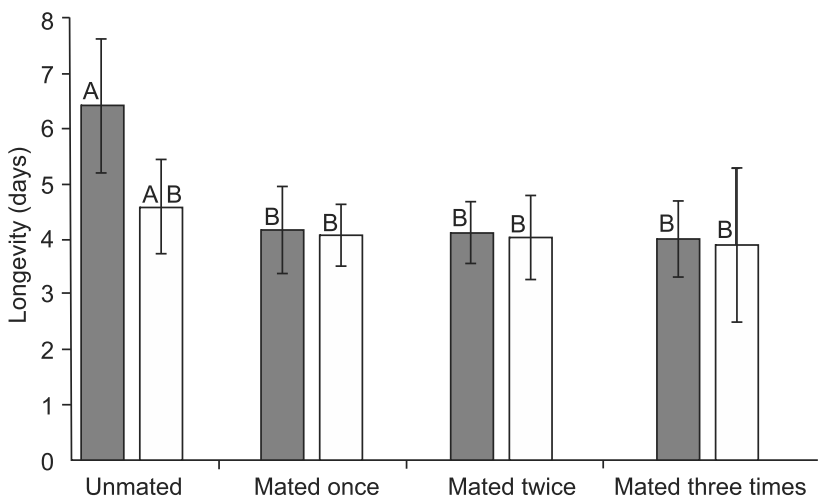
Figure 4. Longevity of Spodoptera dolichos females (dark bars) and males (empty bars), that unmated $(n=4)$, mated once $(n=10)$, twice $(n=8)$ or three times $(n=3)$. One couple per cage at $25 \pm$ $1{ }^{\circ} \mathrm{C}, 70 \pm 10 \% \mathrm{RH}$ and a 14 hour photophase. Means followed by the same letter are not statistically different from each other by Tukey test, at $5 \%$ probability. 


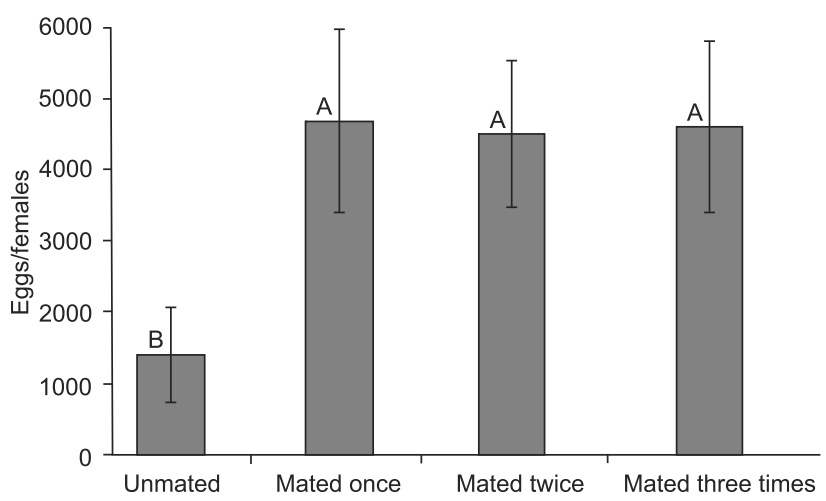

Figure 5. Mean fecundity of Spodoptera dolichos that unmated ( $\mathrm{n}$ $=4)$, mated once $(n=10)$, twice $(n=8)$ or three times $(n=3)$. One couple per cage at $25 \pm 1{ }^{\circ} \mathrm{C}, 70 \pm 10 \% \mathrm{RH}$ and a 14 hour photophase. Means followed by the same letter are not statistically different from each other by Tukey test, at $5 \%$ probability.

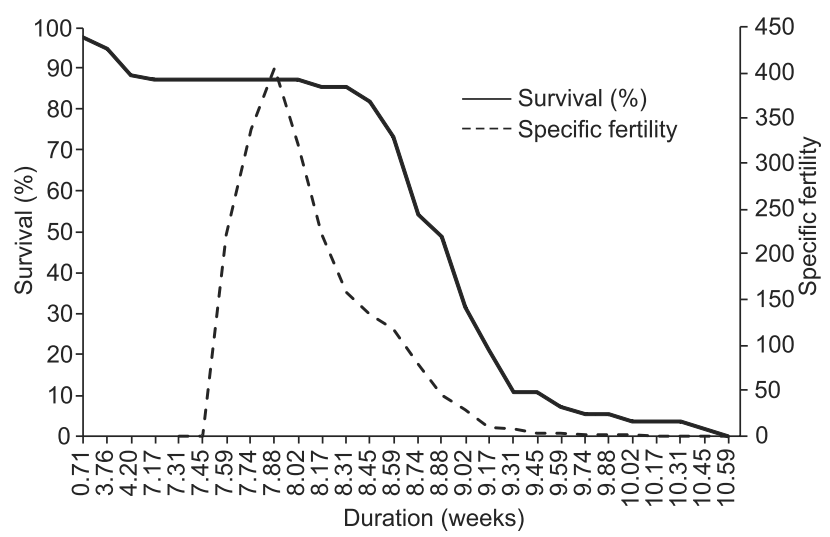

Figure 6. Relation between fertility $(\mathrm{mx})$ and survival rate $(\mathrm{Ix})$ of Spodoptera dolichos reared on an artificial diet at $25 \pm 1{ }^{\circ} \mathrm{C}, 70 \pm$ $10 \% \mathrm{RH}$ and a 14 hour photophase.

daily intrinsic rate of increase (rm) and the daily finite rate of increase $(\lambda)$ were $\mathrm{rm}=0.133$ and $\lambda=1.142$.

\section{DISCUSSION}

The longevity (Table 1) and duration of the immature phase (Montezano et al. 2015) of S. dolichos (male forewing length $18-21 \mathrm{~mm}$ ) encompassed a total of 63.1 days, which is much longer than in smaller species (Pogue 2002) raised in the same conditions, such as $S$. albula (male forewing length 10$14.5 \mathrm{~mm}$ ) and S. eridania (male forewing length $13-15.5 \mathrm{~mm}$ ) (Montezano et al. 2013a,b, 2014a,b). However, longevity and the duration of the immature stages were similar to those reported for Spodoptera cosmioides (Walker, 1858) (male forewing length $16-20 \mathrm{~mm}$ ), whose size is similar to that of $S$. dolichos when reared under similar environmental conditions and artificial diet (BAVARESCO et al. 2004). Therefore, the results indicate that $S$. dolichos, one of the largest species of the genus (Pogue 2002), also presents the longest periods of development.

Nevertheless, as demonstrated for other species of the genus (Kehat \& Gordon 1975, Etman \& Hooper 1979, Ellis \& Steele 1982, Rogers \& Marti Jr 1997, Montezano et al. 2013b), analysis of the results comparing longevity as a function of the number of matings (Fig. 4) indicates that the number of matings is an important factor to be included in longevity studies, especially considering the prolonged pre-oviposition and oviposition periods of unfertilized females $t$ (Figs. 2-3).

Considering the data on immature stages (50.2 days), the average longevity of $S$. dolichos adults corresponds to $20.5 \%$, or more than one-fifth of their entire life cycle. This is less than the longevity obtained for S. albula (28.3\%) (MonteZANo et al. 2013a, 2014a) and S. eridania (24.5\%) (Montezano et al. 2013b, 2014b) under the same conditions. Moreover, the greater longevity of $S$. dolichos, like other species of the genus that have great dispersal and/or migration ability (FERGUSON et al. 1991), is related to its wide distribution within the American Continents, extending between the parallels $30^{\circ}$ North and South (e.g., Pogue 2002, Pastrana 2004).

The number of matings observed in this study is within the range described for S. albula (MonteZANo et al. 2014a) and S. eridania (MontezAno et al. 2013b) reared under the same conditions. The number of matings is similar to the data obtained for Spodoptera frugiperda (J.E. Smith, 1797) by MuRúa et al. (2008). These authors found very discordant values between different S. frugiperda populations in Argentina (0.78 to 2.32 spermatophores per female). Regarding the absence of mating in some $S$. dolichos couples, they reported that in some groups of $S$. frugiperda more than $20 \%$ of the females did not mate. The strong positive correlation between the number of copulations and fecundity obtained in this study, also observed with $S$. eridania (Montezano et al. 2013b) and S. frugiperda (Milano et al. 2008), suggests that a greater number of $S$. dolichos individuals per cage would also increase the number of copulas.

The negative correlation observed between the number of copulas and the pre-oviposition period (Fig. 2) indicates that the pre-oviposition period of $S$. dolichos increases when individuals mate less often or do not mate at all, which is also reflected in their prolonged longevity. This result was also reported for S. eridania (Montezano et al. 2013b), Spodoptera littoralis (Boisduval, 1833) (Kehat \& Gordon 1975, ElLis \& STEele 1982), Spodoptera litura (Fabricius, 1775) (ETMan \& Hooper 1979) and Spodoptera exigua (Hübner, 1808) (Rogers \& MARTI JR 1997).

In the same way, the significant negative correlation between the number of copulas and oviposition period (Fig. 3) is related to the interaction between egg production and metabolism (Hou \& SHENG 1999). It is postulated that multiple fertilizations stimulate egg production and accelerate energy consumption, reducing the resources available for somatic 
maintenance. However, a reduced egg laying period associated with a greater number of copulations, as described by Hou \& SHENG (1999), is likely related with the increase in the reproductive activity ofo the females that copulated more.

The pre-oviposition period of $S$. dolichos (Table 1), especially of fertilized females (Fig. 2), lasts at least one more day than in S. albula and S. eridania (MontezAno et al. 2013b, 2014b) under the same conditions. Ultimately, the sexual maturity of S. dolichos occurs soon after emergence, as with other representatives of Spodoptera (e.g., ETMAN \& HoOpER 1979, HABIB et al. 1983, Tisdale \& SAPpington 2001, Busato et al. 2006). Our results indicate that the initial fertilization period of $S$. dolichos must be between the second and the third day after emergence. However, the onset of oviposition, at least in the first days after emergence, is conditioned by the occurrence of the first mating, as observed for S. exigua (Roger \& MARTi JR 1997), S. eridania (Montezano et al. 2013b) and S. albula (Montezano et al. 2014a).

The fertility of $S$. dolichos was highly variable, with approximately 4,000 eggs per female (Table 1 ), when considering adults from pupae of average weight. The fertility of this species is much higher than that observed in $S$. albula and $S$. eridania reared under the same conditions (MonTEZANo et al. 2013b, 2014a). It was also higher in S. frugiperda (male forewing length $10.5-15 \mathrm{~mm}$ ) reared under similar conditions of temperature and diet (Busato et al. 2006), and S. littoralis (male forewing length 12-16 mm (Sorour et al. 2011). In general, fecundity of $S$. dolichos was similar to that described for $S$. cosmioides. However, BAVARESCO et al. (2004) reported that when larvae of $S$. cosmioides were fed a more suitable artificial diet and adults fed $10 \%$ honey solution, fecundity was greater (4,844.4 eggs/female) than in $S$. dolichos. Nevertheless, in same study, the fecundity of $S$. cosmioides $(3,753.0$ and 1,654.8 eggs/ female) was lower than of $S$. dolichos when larvae were feed two other, less suitable artificial diets.

Two fundamental factors are attributed to the differences in fertility found among the various studies: a) adequacy of the diet, since the pupae of the most fertile specimens reported in the literature were heavier; similar evidence was observed in S. eridania (MonTEZANo et at. 2013a), S. cosmioides (BAVARESCO et al. 2004), S. frugiperda (Busato et al. 2006); and b) fertilization of females (Fig. 5), when considering only the data from females that mated, the fecundity increases to 4,595.8, similar to the maximum reported for $S$. cosmioides, 4,844.4 eggs/female, that received a more suitable diet (BAVARESCO et al. 2004).

The high egg viability $(97.5 \%)$ is correlated with the fertilization of females that had one or two spermatophores. This percentage agrees with the 94.5 and $97.8 \%$ observed for fertilized females of $S$. albula and S. eridania under the same conditions (Montezano et al. 2013b, 2014a), and generally agrees with studies on representatives of the genus Spodoptera where it is demonstrated that multiple matings show an increase in reproductive capacity and fertility (KeHAT \& GoRdon 1975, SADEK 2001, Sadek \& Anderson 2007, Busato et al. 2008, Milano et al. 2008).
Despite the high fecundity and fertility (Table 1 ), the biotic potential $\left(7.138 \times 10^{18}\right.$ individuals/female/year) of $S$. dolichos was lower than that observed for S. albula and S. eridania under the same conditions (Montezano et al. 2013b, 2014a), especially influenced by the long duration of the life cycle, represented by a mean generation time (T) of 56.19 days. Despite this, the high value of net reproductive rate (Ro) was equal to $1,711.98$ females per generation, the daily intrinsic rate of increase $(\mathrm{rm}=0.133)$ and the daily finite rate of increase $(\lambda=$ 1.142 ) were less than those observed for $S$. albula and S. eridania under same conditions (Montezano et al. 2013b, 2014a).

Our results, compared to other studies (e.g. BAVARESCO et al. 2004, Busato et al. 2006, Montezano et al. 2013b, 2014a), indicate that larger Spodoptera species take longer to develop and have higher fecundity. Therefore, the increase in fecundity compensates for the longer developmental period of larger species, for instance $S$. dolichos (present study) and $S$. cosmioides (BAVARESCO et al. 2004), i when compared with smaller species, for instance $S$. albula (Montezano et al. 2013a), S. eridania (Montezano et al. 2014b) and S. frugiperda (Busato et al. 2006).

The maximum rate of population increase of $S$. dolichos (Fig. 6) happens in the beginning of the adult stage, especially driven by the higher fertility and low mortality of the immature individuals shortly after emergence. These observations are similar to those reported in other studies conducted with representatives of Spodoptera where the highest fertility values are observed during the first days after emergence (Кенат \& Gordon 1975, SadeK 2001, Bavaresco et al. 2004, Murúa \& Virla 2004, Busato et al. 2006, Montezano et al. 2013b, 2014a).

The results of this study, in addition to the $S$. albula and S. eridania studies (Montezano et al. 2013b, 2014a), demonstrate that a reduction, or delay, in the number of copulas negatively influences the population parametersI. This result highlights the the relevance of studies that aim to identify and to use $S$. dolichos pheromones (e.g. Mitchell \& Tumlinson 1973, LaLanneCAssou et al. 1994, MEAGHer 2001) to delay,prevent, or reduce it mating in nature (CARDE \& MINKS 1995), as a strategy for the integrated management of this pest species.

\section{ACKNOWLEDGEMENTS}

To CNPq, for granting a Master's Fellowship to the first author (process 557269/2010-5) and for financial assistance (process 482627/2010-7).

\section{LITERATURE CITED}

Bavaresco A, Garcia MS, Grützmacher AD, Ringenberg R, Foresti J (2004) Adequação de uma dieta artificial para a criação de Spodoptera cosmioides (Walk.) (Lepidoptera: Noctuidae) em laboratório. Neotropical Entomology 33(2): 155-161. doi: 10.1590/S1519-566X2004000200005 
Busato Gr, Garcia MS, Loeck AE, Zart M, Nunes AM Bernardi O, Andersson FS (2006) Adequação de uma dieta artificial para biótipos "milho" e "arroz" de Spodoptera frugiperda (Lepidoptera: Noctuidae). Bragantia 65(2): 317-323. doi: 10.1590/S0006-87052006000200014

Busato GR, Loeck AE, Garcia MS, Bernardi O, Zart M, Nunes AM, ZAZYCKI LCF (2008) Compatibilidade reprodutiva entre biótipos "milho" e "arroz" de Spodoptera frugiperda (J.E. Smith) (Lepidoptera: Noctuidae). Revista Brasileira de Agrociências 14(2): 273-278.

Cardé RT, Minks AK (1995) Control of moth pests by mating disruption: successes and constraints. Annual Review of Entomology 40: 559-585. doi: 40.010195.003015

Ellis PE, Steele G (1982) The effect of delayed mating on the fecundity of females of Spodoptera littoralis (Boisduval) (Lepidoptera: Noctuidae). Bulletin of Entomological Research 72(2): 295-302. doi: 10.1017/S0007485300010592

ETMAN AAM, Hooper GHS (1979) Developmental and reproductive biology of Spodoptera litura (F.) (Lepidoptera: Noctuidae). Journal of the Australian Entomological Society 18(4): 363372. doi: 10.1111/j.1440-6055.1979.tb00868.x

Ferguson DC, Hilburn DJ, Wright B (1991) The Lepidoptera of Bermuda: Their food plants, biogeography, and means of dispersal. Memoirs of the Entomological Society of Canada Supplement 158: 3-105. doi: 10.4039/entm10273fv

Habib MEM, Paleari ML, Amaral EC (1983) Effect of three larval diets on the development of the armyworm, Spodoptera latifascia Walker, 1856 (Lepidoptera: Noctuidae). Revista Brasileira de Zoologia 1(3): 177-182. doi: 10.1590/S010181751982000300007

Hoffmann-Campo CB, Oliveira EB, Moscardi F (1985) Criação massal da lagarta da soja (Anticarsia gemmatalis). Londrina, Embrapa-CNPSo, Documentos 10, 23p.

Hou ML, SHeng CF (1999) Fecundity and longevity of Helicoverpa armigera (Lepidoptera: Noctuidae): effects of multiple mating. Journal of Economic Entomology 92(3): 569-573. doi: $10.1093 /$ jee/92.3.569

Kehat M, Gordon D (1975) Mating, longevity, fertility and fecundity of the cotton leaf-worm, Spodoptera littoralis (Boisd.) (Lepidoptera: Noctuidae). Phytoparasitica 3(2): 87102. doi: 10.1007/BF03158291

Lalanne-Cassou B, Silvain J F, Monti L, Malosse C (1994) Description of a new species of Spodoptera from French Guiana: S. descoinsi (Lepidoptera: Noctuidae: Amphipyrinae), discovered with the help of sex attractants. Annales de la Société Entomologique de France 30: 25-32.

Meagher JR RL (2001) Collection of soybean looper and other noctuids in phenylacetaldehyde-baited field traps. Florida Entomologist 84(1): 154-155.

Milano P, Berti Filho E, Parra JRP, Cônsoli FL (2008) Influência da temperatura na frequência de cópula de Anticarsia gemmatalis (Hübner) e Spodoptera frugiperda (J.E. Smith) (Lepidoptera: Noctuidae). Neotropical Entomology 37(5):
528-535. doi: 10.1590/S1519-566X2008000500005

Mitchell ER, Tumlinson JH (1973) An attractant for males of Spodoptera dolichos (Lepidoptera: Noctuidae). Annals of the Entomological Society of America 66(4): 917-918. doi: 10.1093/aesa/66.4.917

Montezano DG, Specht A, Sosa-Gómez DR, Roque-Specht VF, Bortolin TM, Fronza E, Pezzi P, Luz PC, Barros NM (2013a) Immature stages of Spodoptera albula (Walker) (Lepidoptera: Noctuidae): Developmental parameters and host plants. Anais da Academia Brasileira de Ciências 85(1): 271-284. doi: 10.1590/S0001-37652013000100013

Montezano DG, Specht A, Sosa-Gómez DR, Roque-Specht VF, BarROs NM (2013b) Biotic potential and reproductive parameters of Spodoptera eridania (Stoll) (Lepidoptera, Noctuidae) in the laboratory. Revista Brasileira de Entomologia 57(3): 340345. doi: 10.1590/S0085-56262013005000026

Montezano DG, Specht A, Sosa-Gómez DR, Roque-Specht VF, Bortolin TM, Fronza E, Pezzi P, Luz PC, Barros NM (2014a). Biotic potential, fertility and life table of Spodoptera albula (Walker) (Lepidoptera: Noctuidae), under controlled conditions. Anais da Academia Brasileira de Ciências 86(2): 723-732. doi: 10.1590/0001-3765201402812

Montezano DG, Specht A, Sosa-Gómez DR, Roque-Specht VF, BarRos NM (2014b). Immature Stages of Spodoptera eridania (Lepidoptera: Noctuidae): Developmental Parameters and Host Plants. Journal of Insect Science 14(1): 1-11. doi: 10.1093/jisesa/ieu100

Montezano DG, Sosa-Gómez DR, Paula-Moraes SV, Roque-Specht VF, Fronza E, Barros NM, Specht A (2015). Immature development of Spodoptera dolichos (Fabricius) (Lepidoptera: Noctuidae). Neotropical Entomology. doi: 10.1007/s13744-0150333-2

Murúa MG, Virla E (2004) Population parameters of Spodoptera frugiperda (Smith) (Lep.: Noctuidae) fed on corn and two predominant grasses in Tucuman (Argentina). Acta Zoológica Mexicana (n.s.) 20(1): 199-210.

Murúa MG, Vera MT, Abraham S, Juaréz ML, Prieto S, Head GP, WILLINK E (2008) Fitness and mating compatibility of Spodoptera frugiperda (Lepidoptera: Noctuidae) populations from different host plant species and regions in Argentina. Annals of the Entomological Society of America 101(3): 639-649. doi: 10.1603/0013-8746(2008)101[639:FAMCOS]2.0.CO;2

Pastrana JA (2004) Los Lepidópteros Argentinos: sus plantas hospedadoras y otros substratos alimenticios. Buenos Aires, Sociedad Entomológica Argentina, 334p.

Pogue GM (2002) A world revision of the genus Spodoptera Guenée (Lepidoptera: Noctuidae). Memoirs of the American Entomological Society 43: 1-202.

Rogers CE, MARTI JR OG (1994) Reproductive potential of once mated moths of the fall armyworm (Lepidoptera: Noctuidae). Florida Entomologist 77(4): 402-410. doi: 10.2307/3495694

Rogers CE, Marti Jr OG (1997) Once-mated beet armyworm (Lepidoptera: Noctuidae): effects of age at mating on fecun- 
dity, fertility, and longevity. Environmental Entomology 26(3): 585-590. doi: 10.1093/ee/26.3.585

SADEK MM (2001) Polyandry in field-collected Spodoptera littoralis moths and laboratory assessment of the effects of male mating history. Entomologia Experimentalis et Applicata 98(2): 165-172. doi: 10.1046/j.1570-7458.2001.00771.x

SAdek MM, Anderson P (2007) Modulation of reproductive behavior of Spodoptera littoralis by host and non-host plant leaves. Basic and Applied Ecology 8(5): 444-452. doi: 10.1016/j.baae.2006.08.001

Silva AGA, Gonçalves CR, Galvão DM, Gonçalves AJL, Gomes J, SiLVA MN, Simoni L (1968). Quarto catálogo dos insetos que vivem nas plantas do Brasil: seus parasitos e predadores. Parte II, $1^{\circ}$ tomo, Insetos, hospedeiros e inimigos naturais.
Rio de Janeiro. Ministério da Agricultura, 622p.

Silveira-Neto S, Nakano O, Barbin D, Villa Nova NA (1976). Manual de ecologia dos insetos. São Paulo, Editora Agronômica Ceres, 420p.

Sorour MA, Khamiss O, EL-Wahab ASE, El-Sheikh MAK, Abul-Ela $S$ (2011) An economically modified semi-synthetic diet for mass rearing the Egyptian cotton leaf worm Spodoptera littoralis. Academic Journal of Entomology 4(3): 118-123.

Tisdale RA, SAppington TW (2001) Realized and potential fecundity, egg fertility, and longevity of laboratory-reared female beet armyworm (Lepidoptera: Noctuidae) under different adult diet regimes. Annals of the Entomological Society of America 94(3): 415-419. doi:10.1603/00138746(2001)094[0415:RAPFEF]2.0.CO;2

Submitted: 25 July 2015

Received in revised form: 10 September 2015

Accepted: 21 September 2015

Editorial responsibility: Gabriel L.F. Mejdalani 